\title{
ディジタルスチルカメラ用画像符号化方式
}

\author{
正会員 佐々木 実 ${ }^{\dagger}$, 正会員 小野 朋 子” \\ 正会員 高 橋 貞 夫 $^{\dagger \dagger}$, 正会員 渡 邊 敏 明 ${ }^{\dagger+}$
}

\section{Picture Coding for Digital Still Camera}

\author{
Minoru Sasaki ${ }^{\dagger}$, Tomoko Ono $^{\dagger}$, Sadao Takahashi ${ }^{\dagger \dagger}$ and Toshiaki Watanabe ${ }^{\dagger+}$
}

\begin{abstract}
This paper describes a picture-coding technology for a digital still camera which records still images on a memory card The JPEG (Joint Photographic Experts Group) is working on standardizing the digital compression and coding of still images. It is desırable to apply this standard to the digital still camera However, the number of bits to record a fixed number of images on a memory card is comparatively small We propose a method of controlling the bit rate by calculating the activity of images before coding The quantize matrix and the bit allocation for each coding block are determined by the image and the block activity As a result, the number of images recordable on a memory card is fixed and the coded data can be decoded with a standard JPEG decoder
\end{abstract}

\section{1. ま え がき}

即時性, ランニングコストを考え, VTR と同様な 磁気記録の技術を使って, 小型 (2インチ)のフロッピ ーディスクに静止画像をアナログ信号として記録する 電子スチルカメラが開発され, 商品化されている.こ の方式の電子スチルカメラは CCD で撮像した信号を ビデオ信号に変換し, フロッピーディスクに FM 記 録するものである.VTR, フロッピーディスクなど の従来技術が応用でき, また, 価格の安い磁気記録媒 体にフィールド画像であるが 50 枚記録可能である.

一方, 画像信号をディジタル化して, 半導体メモリ 一に記録するディジタルスチルカメラの開発も進んで (る ${ }^{12)}$. 画像入力素子が撮像管から固体撮像素子に
変わり, 入力信号が最初から空間的に離散值であるこ と, 静止画像といえどもディスプレイには数十フレー ム/秒でリフレッシュしながら表示するため, フレー ムメモリーが必要であること, すなわち, 入出力がデ イジタル向きであることから, 電子スチルカメラシス テム全体をディジタル化することが有利である.

半導体メモリーに画像信号をディジタルで記録する 方式は以下の利点, および欠点を有する。

[利点]

（1）コピーや編集時に記録信号が劣化しない.

（2）記録媒体, ヘッドの回転, 移動などのメカニ ズムを必要とせず, 信頼性が高い

（3）LSI 化がしやすく, 小型, 軽量化, 低価格化 が容易.

キーワード: ディジタルスチルカメラ, 静止画符号化, JPEG, ハフマン符号化

1991 年 9 月 27 日受付

†株式会社東芝 映像メディア技術研究所（テ 235 横捠市磯子区新杉田町 8, TEL 045-756-3585)

†† 株式会社東芝 総合研究所（２21 川崎市幸区小向東芝町 1, TEL 044-511-2152）

$\dagger$ Video and Electronıcs Medıa Engıneerıng Laboratory, Toshıba Corporatıon (8, Shınsugita-cho, Isogo-ku, Yokohama 235, Japan)

†† Research and Development Center, Toshiba Corporation (1, Komuka1 Toshiba-cho, Sawwa-ku, Kawasak1 221, Japan) 
（4）画像ファイル，画像処理が容易.

（5）コンピュータ, 伝送機器など, 他のシステム との接続性が良い。

\section{〔欠点〕}

（1）半導体メモリーの価格が磁気記録媒体に比べ 高価.

（2）画像のデー夕量は膨大であり，1 画面の記録 に要するメモリー容量が大きい.

半導体メモリーの集積度は年々増大しており, ビッ 卜当たりの単価も低下しているが, 画像信号をディジ タル記録する場合のデー夕量は，例えばテレビ 1 画面 で 4 6 Mbにもなるため, 画質劣化がない, あるい は目立たないようにデー夕量を削減する技術が重要で ある。

本論文では，ディジタルスチルカメラに必須な符号 化技術について論じ，特にメモリーカードに記録する 上で重要となる符号化後のデー夕量を制御する方法を 提案した。符号化に先立ち画像のアクティビティを求 め量子化テーブルを決定し，実際に符号化を行う時に はさらにブロックごとのアクティビティを利用して各 ブロックへのビット配分を行う. 符号化後のビット数 を細かく直接制御することにより必ず設定デー夕量以 下にできるため，メモリーカードに記録できる画像枚 数が保証されるようになった。ブロックビット配分を 行っても画質劣化を増加させることはなく, しかも符 号化デー夕は標準の JPEG デコーダで復号可能なた め, JPEG に従ったシステムとのデー夕の互換性もと れる。

\section{2. ディジタルスチルカメラの構成}

ディジタルスチルカメラの構成を図 1 に示した ${ }^{3)}$. $\mathrm{CCD}$ の出力は低雑音増幅, ホワイトバランス, ガン マ補正後, A/D 変換器によりディジタル化される. ディジタルデータは信号処理回路により輝度信号 $(\mathrm{Y})$ と色差信号 $\left(\mathrm{C}_{\mathrm{R}}, \mathrm{C}_{\mathrm{B}}\right)$ に変換される. $\mathrm{Y}, \mathrm{C}_{\mathrm{R}}, \mathrm{C}_{\mathrm{B}}$ はメ モリーカードの容量, 画質を考慮し, デー夕の圧縮を 行いメモリーカードに記録される。

メモリーカードは電池バックアップされた SRAM または EEPROM で構成される。

なお，以下では符号化対象画像として，NTSCの
テレビ受像機で得られる最高の画質を考え，次のよう にした。

・画素数

$$
\begin{aligned}
& \mathrm{Y}: 768 \mathrm{H} \times 488 \mathrm{~V} \\
& \mathrm{C}_{\mathrm{R}}: 384 \mathrm{H} \times 488 \mathrm{~V} \\
& \mathrm{C}_{\mathrm{B}}: 384 \mathrm{H} \times 488 \mathrm{~V}
\end{aligned}
$$

・量子化各 8 ビット, 量子化レベルは CCIR Rec. 601 に準拠

・ノンインタレース

ただし, 後述する符号化方式は, より高精細画像へ の適応が可能なものである.

\section{3. 符号化方式に要求される事項}

画像の情報圧縮を目的とした高能率符号化の研究の 歴史は古く，さまざまな方式が開発されてきている． 我々はこれまで各種の符号化方式を検討し, 装置も作 製してきた")。ディジタルスチルカメラに要求される 項目を以下に述べる.

（1） カメラに搭載可能なハード規模

半導体技術の向上によりかなり複雑なアルゴリズム でも LSI 化が可能となってきている，消費電力，実 装面積から判断することになるが, 数チップの LSI で構成できることが条件である.

（2）連写可能な符号化速度

小型カメラでは $2 \sim 3$ コマ/秒, 高級カメラでは 5 〜10コマ/秒の連写速度が要求される. したがって, 1 画面を処理する時間は $0.1 \sim 0.5$ 秒程度が要求され る.

（3）高圧縮が望まれるが, 画質に対する要求も厳 しい

例えば, 現在入手可能な 1 MByte のメモリーカー ドで銀塩フィルムの最小単位に近い 12 枚撮りを実現 するために，目標とする圧縮後のビットレートを 2 b/pel とした. 高画質のモードとしては $4 \mathrm{~b} / \mathrm{pel}$, 高 圧縮率モードとして $1 \mathrm{~b} / \mathrm{pel}$ を設定した。

前述の画像フォーマットでは,

\begin{tabular}{lcccc} 
原画 & \multicolumn{2}{c}{$16 \mathrm{~b} / \mathrm{pel}$} & \multicolumn{2}{c}{$6 \mathrm{Mb} / \mathrm{pel}$} \\
$1 / 4$ 圧縮 & 4 & $\prime$ & $1.5 \mathrm{M}$ & $\prime$ \\
$1 / 8 川$ & 2 & $\prime$ & $750 \mathrm{k}$ & $\prime$ \\
$1 / 16 川$ & 1 & $川$ & $375 \mathrm{k}$ & $\prime$
\end{tabular}

となる. $2 \mathrm{~b} / \mathrm{pel}$ では 10 枚, $1 \mathrm{~b} / \mathrm{pel}$ では 20 枚の画像

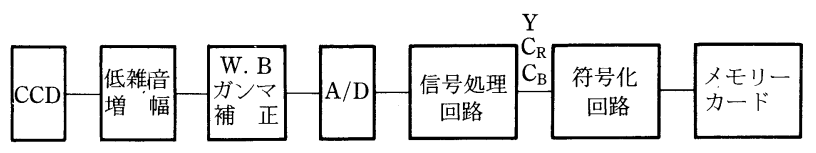

図 1 ディジタルスチルカメラの構成

Block diagram of digital still camera. 
が記録可能である。

（4）他のシステムと符号化デー夕の互換性がある ISO とCCITTでは JPEG (Joint Photographic Experts Group）にて 1986 年からカラー静止画符号化 の国際標準化を進めており ジタルスチルカメラも今後開発されるであろう, 標準 方式に従った画像のファイリング装置, 静止画伝送装 置など, 他の機器とのデー夕の互換性がとれることが 好ましい. JPEGの標準には Sequential-DCT, Progressive-DCT, Lossless, Hierachical の 4 モードが あるが, 高圧縮率でしかも通常使用するには充分な画 像品質が期待でき, ハード規模の点からも Sequential-DCTのうち基本とされている Baseline System が適切であると考える。

（5） 1 画面当たりの符号化後のデー夕量がある程 度一定である

多くの高能率符号化方式ではエントロピー符号化が 採用されており, JPEG Baseline SystemでもDCT 変換後その係数を量子化, ハフマン符号化している. したがって, 画像ごとに符号化後のデー夕量は異な る. 通信や大容量のメモリーを持つファイリング装置 では, 画像ごとに伝送時間や使用メモリー容量が異な っても実用上差支えなく, 逆に画像の性質によらずそ の品質を一定に保つことができるため, 画像ごとの符 号化データ量の制御は行っていない.

ディジタルスチルカメラでは静止画データを比較的 小容量の半導体メモリーに記録するため, ある程度画 像ごとのデータ量を制御する必要がある.1枚のメモ
リーカードに，あるときは 20 画像記録できたが, あ るときは 5,6 枚しか記録できないのでは, 使用者は 不便あるいは不安である.もちろん画質優先で記録枚 数保証は問題としない場合もあろうが, 多くの場合, 記録可能枚数の目安が要求される.

\section{4. データ量制御 DCT 符号化方式}

\section{1 符号化器の構成}

JPEG Baseline System の方式では, 用いる量子化 テーブル，ハフマン符号テーブルによって画像品質, 圧縮率, すなわちデー夕量が変わる。ハフマン符号テ ーブルを画像ごとに最適化しても, ハードの複雑化, 処理時間の増大の割にその符号化効率は数\%向上する のみであるので, 通常はあらかじめ決めたテーブルを 使用するのが得策である。

ハフマン符号のような可変長符号を使用した場合に おいて, デー夕量を制御するには次のような方法があ る.

(1) まず暫定の量子化テーブルを用いて画面全体を 符号化し, 得られた総デー夕量に応じて量子化テ ーブルを変更して再度符号化を行う．これを許容 デー夕量になるまで繰返す。

(2) 順次ブロック毎に符号化を行っていくが, 累積 デー夕量の多少に従って次のブロックに使用する 量子化テーブルを決めながら符号化を進める.

(3) 決められた量子化テーブルを用いて符号化を進 め, 累積デー夕量が所定の值に達したら打切る。

(4) あらかじめ何らかの方法で画面の細かさに応じ

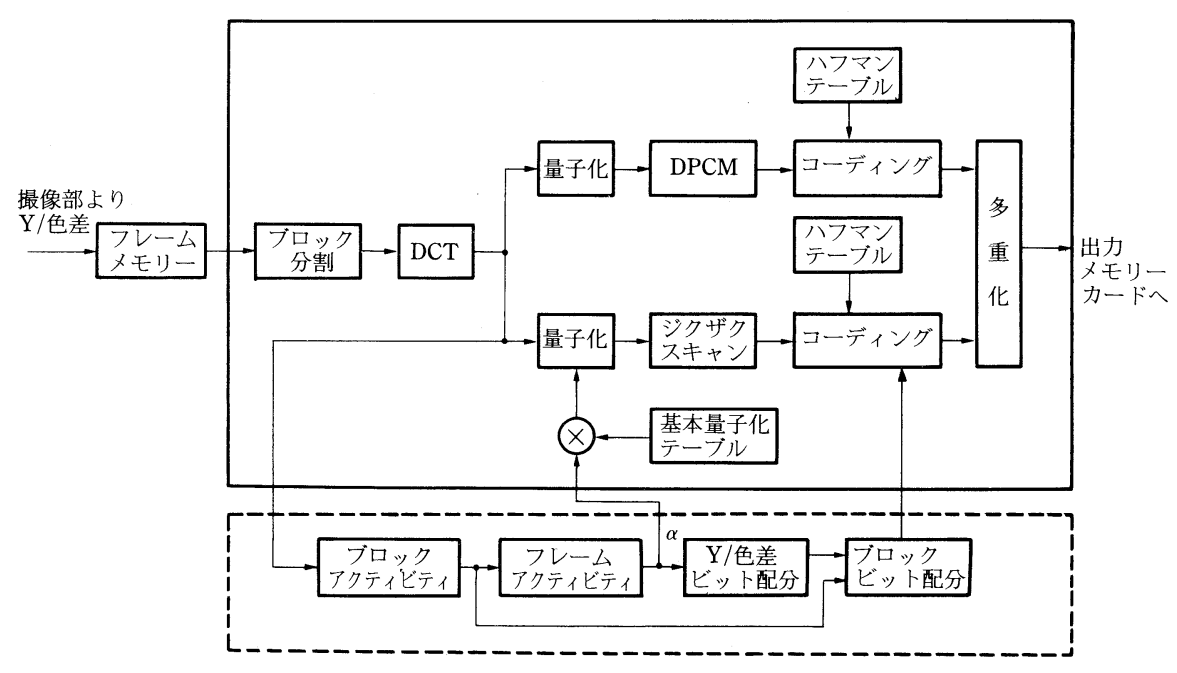

図 2 デー夕量制御 DCT 方式の構成

Block diagram of bit rate control DCT coding method. 
て量子化テーブルを決定し, さらに各ブロックに そのブロックの細かさに応じてデー夕量を割当て る.

(1)の方法では量子化テーブルの更新法にもよるが, 1 画面符号化に最悪 10 回以上の繰返しが必要となる. また $2 \sim 3$ 回の符号化で量子化テーブルを予測する方 法も提案されているが(6), 設定デー夕量を越えること がある. (2)は 1 画面符号化中に複数の量子化テーブル を使用することになり，JPEGの規格からはずれる． (3)は画像の一部が欠落することになる . (4)の方式は各 ブロックごとにデー夕量を割当てるため総デー夕量の 制御が正確にでき，しかも設定デー夕量を越えること がなく, 最適と考えられる。

提案方式のブロック図を図 2 に示した。実線内は JPEG Baseline System のブロック図である. 破線内 がデー夕量制御部である.

JPEG Baseline System の符号化方式の概略を述べ る7). 入力画像は $8 \times 8$ 画素のブロックに分割し, 各 ブロックで 2 次元 DCT 変換される. 変換後 $8 \times 8$ の DCT 係数が得られる. 図 3 に示す左上の係数が直流 成分を表し，残りの 63 個が交流成分であり，右下方 向に行くにつれ高周波成分となる. 各係数は量子化テ ーブルを用いて係数ごとに異なる值で線形量子化され る. 量子化後, 直流係数は 1 つの前のブロックの直流 係数との差を求め，その差分值をその大きさによりグ ループに分類し, グループ番号とグループ内の差分值 を示す付加ビットに分けられる.グループ番号は八フ マン符号テーブルで符号化され, 続いて付加ビットが 付けられる. 交流係数は図 3 に示すように, 低周波成 分から高周波成分へジグザグ走查し，1次元に並べ直

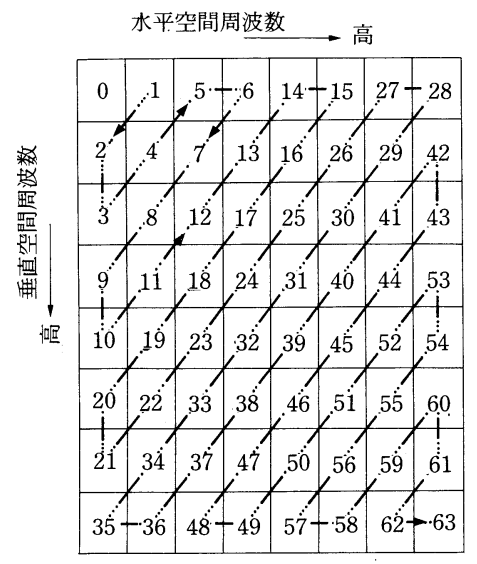

図 3 DCT 係数のジグザグ走査 Zig zag sequence of DCT coefficients.
される．係数が 0 の場合はその連続する長さをランレ ングスとして数え，0以外の場合はその值によりグル 一プ化される．ランレングスと直後の非零の值のグル ープ番号を組にしてハフマン符号化し, 続いてその非 零の值のグループ内の值が付加ビットとして付けられ る. カラー画像の場合は上記の量子化, 符号化を色ご とに行う. 前述のようにディジタルスチルカメラでは 輝度信号 $(\mathrm{Y})$ と色差信号 $\left(\mathrm{C}_{\mathrm{R}}, \mathrm{C}_{\mathrm{B}}\right)$ について行う. 輝 度信号は $96 \times 61$ ブロック，色差信号はそれぞれ $48 \times$ 61 ブロックで構成される。

デー夕量制御部では画像のアクティビティを求め, 量子化テーブルを決定すると共に, 輝度, 色差信号に 割当てるデー夕量およびブロックごとのデータ量を決 める8).

\section{2 符号化手順}

符号化は 2 スキャンで行われる，第 1 スキャンは画 像のアクティビティを求める期間であり，第 2 スキャ ン目に実際の符号化がなされる。

(1) 第1スキャン

フレームメモリーから画像デー夕を読出し, $8 \times 8$ 画素のブロックごとにアクティビティを求め, 全画面 走査後, 全ブロックのアクティビティの総和を求め る. 輝度, 色差信号各々についてアクティビティの総 和を求めた後, 設定デー夕量に合わせ量子化テーブル を決定すると共に, 輝度, 色差信号に割り当てるデー 夕量を決める。

(2) 第 2 スキャン

再度フレームメモリーより画像デー夕を読出し, $8 \times 8$ 画素の 2 次元 DCT 変換を行い, 変換後の各係数 を第 1 スキャンで求めた量子化テーブルで量子化す る. 量子化後のデータは 4.1 節で述べた符号化を行 う. 輝度, 色差それぞれに割当てられたデー夕量を各 ブロックのアクティビティに応じて配分し，各ブロッ クはこの配分ビット数以下となるように制御される.

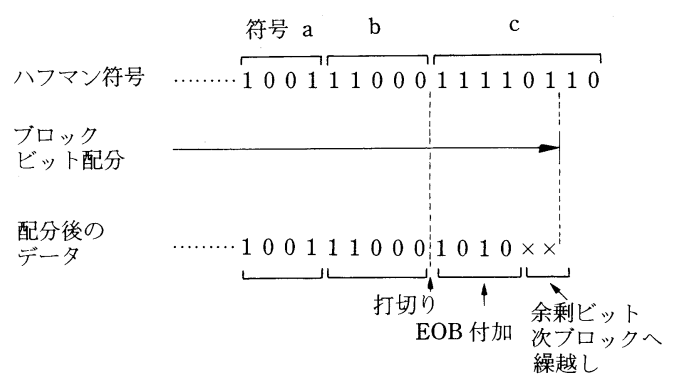

図 4 ブロックビット配分 Block bit allocation. 
直流係数のブロック間差分值は必ず符号化し, 交流係 数は低周波成分から高周波成分にジグザグ走査し，八 フマン符号化を続け，図４に示すようにブロック割当 てビット数以上は打切る. 打切りのあった場合, ブロ ック終了の符号, EOB を付加する。この時発生する 余剰ビットは次のブロックへ繰越す. 輝度, 色差共に ブロックごとにビット数を制御し，1画面の総データ 量を一定值以下に納める.

\section{3 データ量制御の方法}

\section{（1）量子化テーブルの決定}

量子化テーブルを画像ごとに最適化を図ることは実 際には困難なため, 基本量子化テーブルを用意し, こ れに係数 $(\alpha)$ を掛けたものを量子化ステップサイズと した。基本量子化テーブルには JPEG 参考值である 図 5 を用いた。 $\alpha$ は輝度, 色差共通に 1 つのみとし た. 直流係数の量子化値は $\alpha$ によらず一定値 8 とし た. ハフマン符号テーブルは JPEG 参考值を用い, $\alpha$ を変え符号化した後のデー夕量を測り $\alpha$ とビットレ 一トの変化を調べた. ITEの標準画像のうち ITE 1 (カーネーションガール) と ITE 4 (スイスの山 村）について図 6 に示した. 同一の $\alpha$ で量子化した場 合, ビットレートが大幅に変わることがわかる．した がって, 目標のデー夕量となるような $\alpha$ を画像ごと に何らかの方法で決める必要がある.

$\begin{array}{rrrrrrrr}\square & 11 & 10 & 16 & 24 & 40 & 51 & 61 \\ 12 & 12 & 14 & 19 & 26 & 58 & 60 & 55 \\ 14 & 13 & 16 & 24 & 40 & 57 & 69 & 56 \\ 14 & 17 & 22 & 29 & 51 & 87 & 80 & 62 \\ 18 & 22 & 37 & 56 & 68 & 109 & 103 & 77 \\ 24 & 35 & 55 & 64 & 81 & 104 & 113 & 92 \\ 49 & 64 & 78 & 87 & 103 & 121 & 120 & 101 \\ 72 & 92 & 95 & 98 & 112 & 100 & 103 & 99\end{array}$

(a) 輝度信号 $(\mathrm{Y})$

$\begin{array}{llllllll}\square & 18 & 24 & 47 & 99 & 99 & 99 & 99 \\ 18 & 21 & 26 & 66 & 99 & 99 & 99 & 99 \\ 24 & 26 & 56 & 99 & 99 & 99 & 99 & 99 \\ 47 & 66 & 99 & 99 & 99 & 99 & 99 & 99 \\ 99 & 99 & 99 & 99 & 99 & 99 & 99 & 99 \\ 99 & 99 & 99 & 99 & 99 & 99 & 99 & 99 \\ 99 & 99 & 99 & 99 & 99 & 99 & 99 & 99 \\ 99 & 99 & 99 & 99 & 99 & 99 & 99 & 99\end{array}$

(b) 色差信号 $\left(\mathrm{C}_{\mathrm{R}}, \mathrm{C}_{\mathrm{B}}\right)$

図 5 量子化テーブル

Quantization table.

(a) Luminance $(\mathrm{Y})$, (b) chrominance $\left(\mathrm{C}_{\mathrm{R}}, \mathrm{C}_{\mathrm{B}}\right)$

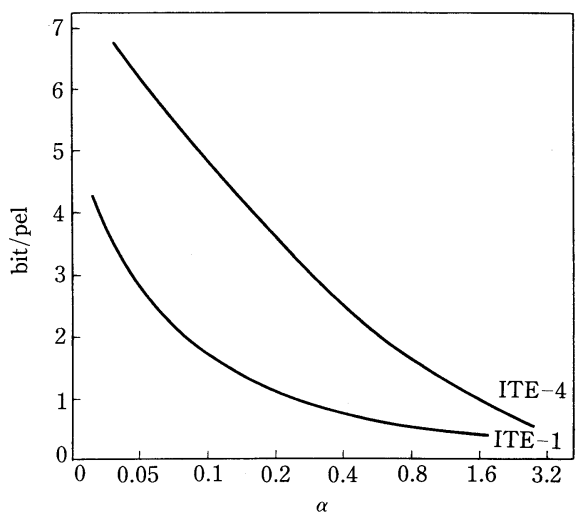

図 $6 \quad \alpha$ とビットレートの関係

Relation between $\alpha$ and bit rate.

(2) アクティビティ

画像のアクティビティと実際の符号化後の総デー夕 量に何らかの相関があれば, 事前にアクティビティを 測ることにより総デー夕量の予測が可能となる.

アクティビティとしては, ブロック内の画素值ある いは DCT 係数の分散, 最大值一最小值, 2 乗和等が 考えられる. 次の 3 条件を満たすアクティビティとし て何を用いるかを検討した。

(1) ブロックのアクティビティと, ハフマン符号化 後のブロックデータ量が比例する.

(2) 1 画面の総アクティビティから簡単な計算で $\alpha$ が求まる。

(3) 輝度, 色差信号の各々の総アクティビティの比 から, 輝度, 色差に配分するデー夕量が簡単に求 まる。

ITE 標準画像 5 枚, 放送用 3 板カメラで撮影した 15 枚, 合計 20 画像について調べた結果, ブロックア クティビティとして,

輝度信号: $A_{c t b y}=\sqrt{\sum \mid \mathrm{DCT} \text { 交流係数 } \mid}$

色差信号 : $A_{c t b c}=k_{1} \cdot \Sigma \mid \mathrm{DCT}$ 交流係数 $\mid$

とすると, ブロックアクティビティとブロックデータ 量がほぼ比例することが確認された. 図 7 ( a ) に輝度 信号における $A_{c t b y}$ と暫定の量子化テーブルで量子 化, 符号化したときの各ブロックの交流係数のデータ 量の分布の例を示した. 図 7 ( b ) は色差信号の例であ る. なお, $k_{1}$ は輝度, 色差のデー夕量配分最適化の ための補正係数であり, $k_{1}=0.03$ とした. 輝度, 色差 信号の各々の総アクティビティを

輝度信号: $A_{c t t y}=\sum A_{c t b y}$

色差信号 : $A_{c t t c}=\sum A_{c t b c}$

1 画面の総アクティビティを

$$
A_{c t t T}=A_{c t t y}+A_{c t t c}
$$




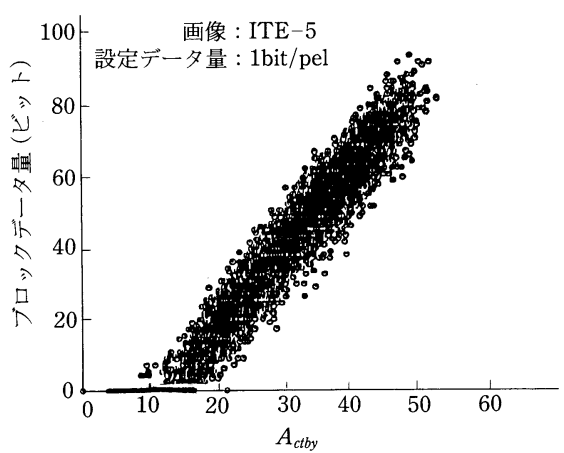

(a) 輝度信号の場合

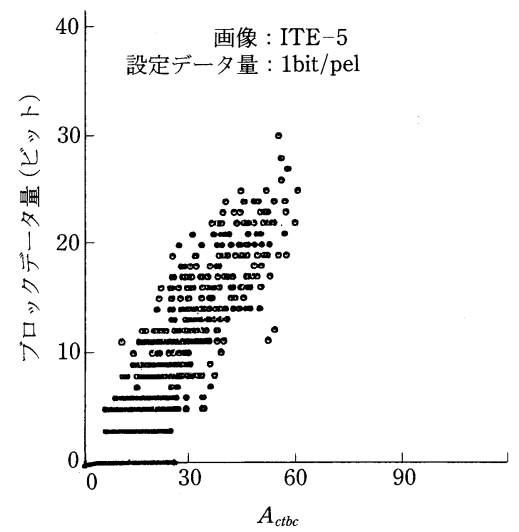

（b）色差信号の場合

図 7 ブロックアクティビティに対するブロックデー 夕量の分布 (ブロックデー夕量は直流係数符号 分を除く)

Relation between block activity and number of block bits.

(a) Luminance, (b) chrominance

とすると次節で示すように $\alpha$ および輝度，色差デー 夕配分の計算が簡単にできる.

(3) $\alpha$ の決定

$A_{\text {cttT }}$ と $\alpha$ の相関を先に述べた 20 画像で調べた. 各画像について $A_{c t t T}$ を計算する。一方, $\alpha$ を変えて 量子化, 符号化し総デー夕量を求め, $1 \mathrm{~b} / \mathrm{pel}$ となる $\alpha\left(\alpha_{1}\right)$ を各画像ごとに求める.

$A_{c t t T}$ を横軸に， $\alpha_{1}$ を縦軸にとると, 20 画像につい ては図 8 に示すようになる。 $\alpha_{1}$ は次の式で近似でき る。

$$
\alpha_{1}=0.86 A_{c t t T} \times 10^{-5}-1
$$

通常の自然画像では $A_{c t t T}-\alpha_{1}$ は直線と考えられる. $2 \mathrm{~b} / \mathrm{pel}, 4 \mathrm{~b} / \mathrm{pel}$ の場合も同様に $\alpha$ の近似式が求ま る.

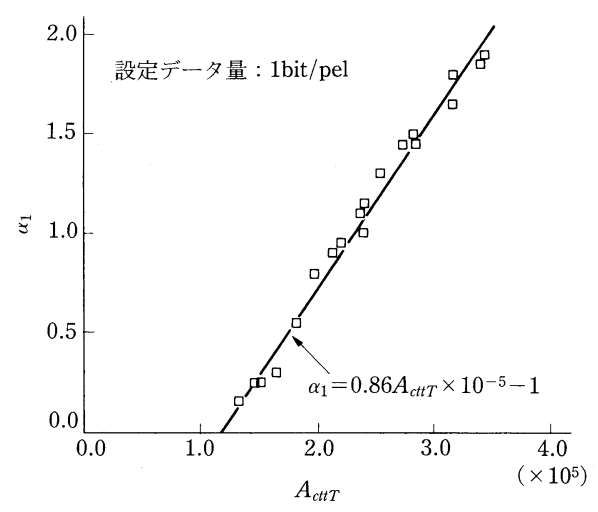

図 8 画像のアクティビティと $\alpha$ の関係 Relation between image activity and $\alpha$.

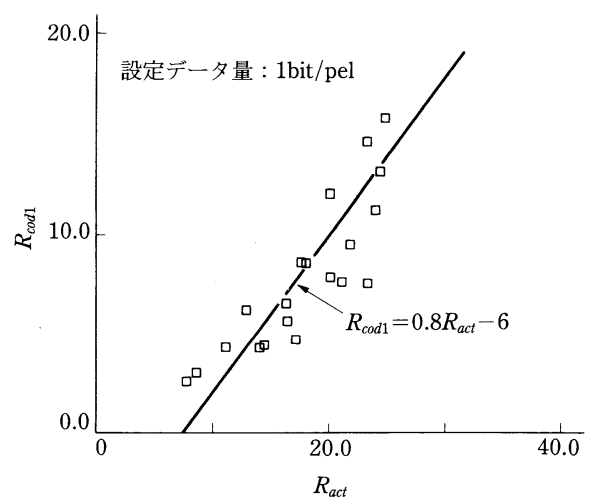

図 9 輝度/色差アクティビティ比とデー夕量比の 関係

Relation between $\mathrm{Y} / \mathrm{C}$ activity ratio and $\mathrm{Y} / \mathrm{C}$ total bit ratio.

（4）輝度/色差デー夕量配分の決定

輝度, 色差信号に配分するデー夕量の比は固定でも よいが，画像ごとに配分比を変えたほうが高画質とな る. $1 \mathrm{~b} / \mathrm{pel}$ となる $\alpha_{1}$ を求め, この $\alpha_{1}$ で実際に符号 化し, そのときの輝度と色差のデー夕量の比 $R_{\text {cod } 1}$ を 求める. 一方, 輝度信号の総アクティビティ $A_{c t t y}$ と 色差信号の総アクティビティ $A_{c t t c}$ の比をとり ,

$$
R_{\text {act }}=A_{c t t y} / A_{c t t c}+k_{2} \cdot \alpha_{1}
$$

を求める。 $\alpha_{1}$ が大きい場合は細かい絵柄であり,こ の場合には輝度信号のデー夕量配分を多くしたほうが 総合画質は良くなるため， $k_{2} \cdot \alpha_{1}$ を補正項として追加 した. $k_{2}=5$ として $R_{\text {cod } 1}$ と $R_{\text {act }}$ を 20 画像について 求めると図 9 に示す結果が得られ， $R_{\operatorname{cod} 1}$ は次式で近 似できる。 


$$
R_{\text {cod } 1}=0.8 R_{\text {act }}-6
$$

設定デー夕量を $N_{T}$ とすると輝度の総デー夕量 $N_{Y}$ は 次式で求められる.

$$
N_{Y}=R_{c o d 1} /\left(R_{c o d 1}+1\right) \times\left(N_{T}-\right.\text { 直流係数 }
$$

符号量 $)+$ 輝度の直流係数符号量

色差の総デー夕量 $N_{c}$ は次式となる.

$$
N_{C}=1 /\left(R_{\operatorname{cod} 1}+1\right) \times\left(N_{T}\right. \text { 一直流係数符号 }
$$$$
\text { 量 })+ \text { 色差の直流係数符号量 }
$$

$2 \mathrm{~b} / \mathrm{pel}, 4 \mathrm{~b} / \mathrm{pel}$ の場合も同様に算出できる.

（5）ブロックビット配分の決定

前節で述べたように輝度/色差各々の総デー夕量を 求めた後, 各ブロックヘビット数を配分する.

各ブロックへ配分するビット数は

輝度のブロックビット数 $=\left(A_{c t b y} / A_{c t t y}\right) N_{Y}$

色差のブロックビット数 $=\left(A_{c t b c} / A_{c t t c}\right) N_{c}$

で与えられる．各ブロックで上の值を越えた場合には 打ち切られる. 打ち切った後に余った余剩ビットは次 のブロックへ繰り返す。

\section{5. シミュレーション結果}

符号化に先立ちブロックごとのアクティビティを求 め， $\alpha$ を決定し量子化テーブルを作成する. 同時に輝 度/色差へ配分するデー夕量を算出する。第 2 スキャ ンで各ブロックごとにビット数を割当てながら符号化 を行う。
この手順で符号化した場合の SNR, ビットレート の例を表 1 に示した．いずれの画像も $2 \mathrm{~b} / \mathrm{pel}$ では画

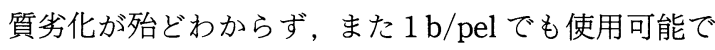
ある.さらに，どの場合でも設定データ量の $90 \%$ 〜 $100 \%$ の範囲に収まっており，本方式は実用上充分 であると考える。

\section{6. む す び}

半導体メモリーカードを記録媒体とするディジタル スチルカメラは, 撮影画像信号がディジタル值で保存 されるため, 伝送, 編集, 加工等が画質劣化なく行え る. 音, 画像, データを混在して扱うマルチメディア システムへの適合性も高く, 静止画入力装置としての 期待も高い．本方式により画像ごとのデー夕量を一定 に制御することが可能となり，メモリーカードに規定 枚数の画像が記録できるようになった，符号化デー夕 は標準の JPEGデコーダで復号可能であるため, JPEG に従った他のシステム, 機器とのデー夕互換性 も取りやすい.

現在は $768 \times 488,640 \times 480$ 画素のように, CCD の 性能により画素数が制限されているが, 八イビジョン 素子を含め, さらに多画素の CCD が開発され, ディ ジタルスチルカメラに採用された場合でも，本方式は 適用可能であり, またシステムの拡張は容易である。

最後に, 本研究を進めるにあたり, 御指導いただい

\begin{tabular}{|c|c|c|c|c|c|c|c|}
\hline 設定デー夕量 & 画 & & ITE-1 & ITE-2 & ITE-3 & ITE-4 & ITE-5 \\
\hline \multirow{5}{*}{$1 \mathrm{~b} / \mathrm{pel}$} & \multirow{3}{*}{$\operatorname{SNR}(\mathrm{dB})$} & $(\mathrm{Y})$ & 40.2 & 39.1 & 40.7 & 27.9 & 28.7 \\
\hline & & $\left(C_{R}\right)$ & 43.1 & 41.5 & 40.9 & 34.6 & 34.6 \\
\hline & & $\left(C_{B}\right)$ & 45.7 & 42.8 & 41.9 & 34.8 & 34.7 \\
\hline & \multicolumn{2}{|c|}{ 輝度/色差デー夕量比 } & 5.1 & 3.8 & 3.0 & 11.0 & 8.8 \\
\hline & \multicolumn{2}{|c|}{ デー夕量(b/pel) } & 0.99 & 0.92 & 0.94 & 0.96 & 0.96 \\
\hline \multirow{5}{*}{$2 \mathrm{~b} / \mathrm{pel}$} & \multirow{3}{*}{$\mathrm{SNR}(\mathrm{dB})$} & $(\mathrm{Y})$ & 43.0 & 41.8 & 42.9 & 32.2 & 32.5 \\
\hline & & $\left(\mathrm{C}_{\mathrm{R}}\right)$ & 44.3 & 43.6 & 44.3 & 36.9 & 37.9 \\
\hline & & $\left(\mathrm{C}_{\mathrm{B}}\right)$ & 47.3 & 46.0 & 47.4 & 37.5 & 37.7 \\
\hline & \multicolumn{2}{|c|}{ 輝度/色差データ量比 } & 5.4 & 3.4 & 2.2 & 6.1 & 5.4 \\
\hline & \multicolumn{2}{|c|}{ デー夕量 (b/pel) } & 1.98 & 2.00 & 2.00 & 1.99 & 1.99 \\
\hline \multirow{5}{*}{$4 \mathrm{~b} / \mathrm{pel}$} & \multirow{3}{*}{$\operatorname{SNR}(\mathrm{dB})$} & $(\mathrm{Y})$ & 45.6 & 44.3 & 48.0 & 36.5 & 35.7 \\
\hline & & $\left(\mathrm{C}_{\mathrm{R}}\right)$ & 45.8 & 45.2 & 46.0 & 40.3 & 41.0 \\
\hline & & $\left(\mathrm{C}_{\mathrm{B}}\right)$ & 49.1 & 48.6 & 49.8 & 40.3 & 40.2 \\
\hline & \multicolumn{2}{|c|}{ 輝度/色差データ量比 } & 2.7 & 2.3 & 2.1 & 4.3 & 4.0 \\
\hline & \multicolumn{2}{|c|}{ デー夕量 (b/pel) } & 3.87 & 3.98 & 3.96 & 3.97 & 3.97 \\
\hline
\end{tabular}

表 1 SNR およびビットレートの例

Exsample of SNR and bit rate 
た総合研究所下村所長, 映像メディア技術研究所入 江所長はじめ関係各位に深く感謝いたします。

\section{〔参考 文 献〕}

1）大地, 大塚, 佐藤, 逢坂, 西, 吉崎: “カードカメラ“FUJIX DS-1 P””, テレビ学技報, 13,22 , pp. 11-16, TEBS'89-30 (Mar. 1989)

2）佐々木, 梅田, 上谷, 田上, 井沢, 瀧澤: “ディジタル電子 スチルカメラ”, テレビ学技報, 13, 22, pp. 17-22, TEBS'8930 (Mar. 1989)

3）佐々木：“電子スチルカメラの現状と将来”, 平 2 連大, S20 -2, pp. 137-140 (Aug. 1990)
4）佐々木：“ディジタルスチルカメラにおける符号化技術”, 東芝レビュー，45, 8 (1990)

5）安田：“カラー静止画符号化国際標準化”, 画電学誌, 18, 6 (June 1989)

6）根本, 大町： “DCT 符号化方式の符号量制御方法”, 信学秋 大, D-45 (1989)

7) 大町, 小野：“カラー静止画符号化国際標準方式 (JPEG) の 概説（その 1)”, 画電学誌, 20, 1, pp. 50-58 (Jan. 1991)

8）渡邊, 塚原, 上谷, 瀧澤, 小野：“固体電子スチルカメラ用 レート適応型 DCT 符号化方式”, 信学春大, 7-141（1989）

9) Chen, Smith: "Adaptive Coding of Monochrome and Color Images”, IEEE Trans., COM-25, 11, pp. 1285-1292 (Nov. 1977)

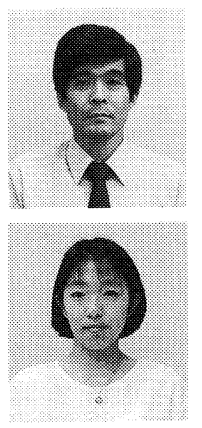

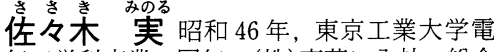
気工学科卒業. 同年, (株) 東芝に入社. 総合 研究所を経て, 現在, 同社映像メディア技術 研究所に勤務. ディジタル映像機器の開発に 従事. 正会員.

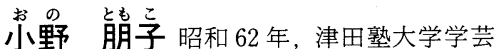
学部数学科卒業. 同年, (株) 東芝に入社. 静 止画像の高能率符号化の研究開発に従事. 現 在, 同社映像メディア技術研究所に所属. 正 会員.

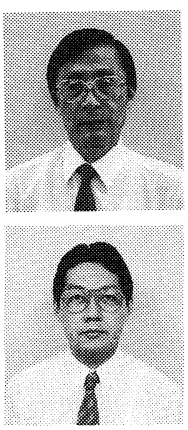

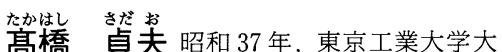
学院修士課程修了. 同年, (株) 東芝に入社. マイクロ波低雑音増幅器, 弾性表面波フィル 夕, 光応用計測制御システム, 光通信, ハイ ビシション機器の研究開発に従事. 現在, 同社 総合研究所技監. 正会員.

渡邊敏明音 昭和 60 年, 北海道大学大学 院工学部研究科修士課程修了. 同年, (株) 東 芝に入社. 総合研究所にてテレビ会議, テレ ビ電話等の動画像圧縮符号化技術の研究，お よびディジタルスチルカメラ等の静止画像圧 縮符号化技術の研究に従事. 正会員. 